\title{
Medvrstniško nasilje med študentkami in študenti: vloga kazalnikov pozitivnega razvoja mladih
}

\author{
Tina Pivec, Ana Kozina
}

\section{Uvod}

Izvajanje in doživljanje nasilja ima lahko za posameznike kratkoročne in dolgoročne posledice, pri čemer se večina raziskav osredinja na pojavnost nasilja predvsem $\mathrm{v}$ obdobju osnovne in srednje šole, čeprav se izvajanje in doživljanje medvrstniškega nasilja pojavlja tudi na prehodu iz mladostništva v odraslost, torej v času študija. Raziskav medvrstniškega nasilja med študentkami in študenti v slovenskem prostoru skorajda ni, čeprav ugotovitve tujih raziskav kažejo, da tudi študenti poročajo o izvajanju in doživljanju nasilja (Lund in Ross, 2017). Ne glede na to, kdaj so posamezniki in posameznice deležni nasilja ali ga sami izvajajo, ima lahko to zanje kratkoročne in dolgoročne posledice (Twemlow in Sacco, 2013), zato je nujno prepoznavanje dejavnikov, ki nanju vplivajo. Zaradi pomanjkanja raziskav na študentski populaciji je ključno raziskati dejavnike, ki napovedujejo nižjo stopnjo verjetnosti za izvajanje določene oblike izvajanja ali doživljanja nasilja.

V raziskovanje varovalnih dejavnikov medvrstniškega nasilja bi bilo tako smiselno vključiti perspektivo pozitivnega razvoja mladih, ki predpostavlja, da v kolikor je razvoj mladostnikov in mladostnic optimalen, obstaja manjša verjetnost težav ponotranjanja in pozunanjanja (npr., anksioznost, depresivnost, delikventnost, izvajanje nasilja; Murry et al., 2014). 
Namen pričujočega prispevka je raziskati pojavnost besedne in odnosne oblike izvajanja in doživljanja nasilja med študenti in študentkami ter preveriti napovedno vrednost posameznih kazalnikov pozitivnega razvoja mladih pri besedni in odnosni obliki izvajanja ter doživljanja nasilja na vzorcu študentk in študentov.

\section{Opredelitev izvajanja in doživljanja medvrstniškega nasilja}

V literaturi obstaja veliko različnih definicij medvrstniškega nasilja. Skozi slednje lahko prepoznamo naslednje skupne značilnosti (Salmivalli in Peets, 2009): namen nasilja je škodovati, izvajanje nasilja traja dalj časa in med nasilnežem ter žrtvijo obstaja razlika v moči. Medvrstniško nasilje se pojavlja v različnih oblikah. To so telesno nasilje (npr. udarci), besedno nasilje (npr. zmerjanje) in odnosno nasilje (npr. socialna izključitev, širjenje govoric) (Marsh et al., 2011). Dodatno lahko med oblike medvrstniškega nasilja štejemo tudi spletno medvrstniško nasilje (Slonje in Smith, 2008). Doživljanje medvrstniškega nasilja se povezuje $z$ negativnimi izidi (npr. depresivnost, anksioznost) (Moore et al., 2017), podobno velja za izvajanje medvrstniškega nasilja (npr. višje tveganje za uživanje prepovedanih substanc in pojav psihiatričnih simptomov) (Nansel et al., 2004). Posamezniki, ki so bili v otroštvu oziroma mladostništvu izvajalci nasilnega vedenja, imajo večjo verjetnost, da bodo nasilje izvajali tudi v odraslosti (Curwen et al., 2011).

Medvrstniško nasilje med študentkami in študenti je komaj v zadnjih letih postalo predmet raziskav (Lund in Ross, 2017; Pörhölä et al., 2020). Glede oblik medvrstniškega nasilja je bilo ugotovljeno, da se v največji meri pojavljata besedno in odnosno nasilje, pri čemer pri besednem nasilju izstopajo grožnje in norčevanje iz posameznika (Pörhölä et al., 2020), medtem ko je telesno nasilje med študentkami in študenti zelo redko (Perry in Blincoe, 2015). V pregledu literature sta Lund in Ross (2016) ugotovila, da je pojavnost doživljanja tradicionalnega nasilja (tj. telesno, besedno in odnosno) med 20 in $25 \%$ udeležencev v raziskavi, medtem ko je med 10 in $15 \%$ udeležencev poročalo, da so bili žrtve spletnega nasilja. Podobna je tudi pojavnost izvajanja medvrstniškega nasilja med študentkami in študenti, saj je 20 \% udeležencev poročalo o izvajanju tradicionalnih oblik medvrstniškega nasilja, medtem ko je zgolj 5 \% udeležencev poročalo o izvajanju spletnega nasilja.

\section{Kazalniki pozitivnega razvoja mladih in medvrstniško nasilje}

Pozitivni razvoj mladih temelji na teoriji relacijskih razvojnih sistemov in se osredotoča na pomen medsebojnega vplivanja posameznikovih značil- 
nosti (notranji viri) in njegovih kontekstov (zunanji viri; npr. šola, družina, skupnost, družba) (Lerner, 2007). Perspektiva predvideva, da je optimalen razvoj mladostnikov možen, ko bodo notranji viri usklajeni $\mathrm{z}$ zunanjimi viri, kar bi naj omogočilo višjo stopnjo pojavnosti kazalnikov pozitivnega razvoja mladih med mladostniki in mladostnicami.

Kazalniki pozitivnega razvoja mladih oziroma $5 \mathrm{C}$-jev so kompetentnost, samozavest, karakter, povezanost in skrb (Bowers et al., 2010). Kompetentnost predstavlja pozitivno mnenje o svojih dejanjih na specifičnih področjih, medtem ko je samozavest opredeljena kot notranji občutek pozitivnega samovrednotenja in samoučinkovitosti. Karakter je opredeljen kot posedovanje etičnih standardov vedenja, ki so skladni z družbenimi in kulturnimi normami. Povezanost predstavlja preplet pozitivnih vzajemnih odnosov posameznika $z$ njegovimi oz. njenimi pomembnimi drugimi, institucijami ter skupnostmi. Skrb združuje empatijo in sočustvovanje. Številne raziskave potrjujejo, da prisotnost kazalnikov pozitivnega razvoja mladih vodi do prispevanja mladostnika h kontekstom, ki jim pripada (npr. družina, šola, vrstniška skupina) (Lewin-Bizan et al., 2010) ter da je višja stopnja izraženosti kazalnikov pozitivnega razvoja mladih negativno povezana s tveganim vedenjem in čustvenimi težavami (Jelicic et al., 2007).

Paradigma pozitivnega razvoja mladih je $\mathrm{v}$ raziskavah med izide $\mathrm{v}$ manjši meri vključevala medvrstniško nasilje, čeprav je medvrstniško nasilje eno izmed nezaželenih vedenj oziroma izidov. Večinoma so tovrstne raziskave vključevale zgolj razvojne vire (Fredkove et al., 2019) ali posamezne kazalnike pozitivnega razvoja mladih, kot je karakter (Hilliard et al., 2014). Če se osredinimo na kazalnike pozitivnega razvoja mladih, je mogoče ugotoviti, da ti zajemajo veliko že do sedaj raziskanih varovalnih dejavnikov medvrstniškega nasilja. Tako lahko skrb povežemo z empatijo (Zych et al., 2019), povezanost $\mathrm{z}$ oporo vrstnikov in prijateljstvom (Kendrick et al., 2012), kompetentnost se nanaša tako na učno kot tudi socialno kompetentnost (Jenkins et al., 2016; Kowalski in Limber, 2013).

\section{Metoda}

\section{Udeleženci}

V pilotni raziskavi projekta Pozitivni razvoj mladih v Sloveniji: razvojne zakonitosti v kontekstu migracij (PYD-SI-MODEL), ki poteka na Pedagoškem inštitutu in Filozofski fakulteti Univerze v Mariboru, je sodelovalo 364 udeleženk in udeležencev (80,5 \% žensk), starih od 19 do 28 let $(M=$ 
22,21; $S D=2,20)$. V raziskavi so sodelovali študentke in študenti vseh študijskih stopenj, največ je bilo študentov in študentk 1. letnika podiplomskega študija $(29,6 \%)$.

\section{Pripomočki}

Učna uspešnost. Za merjenje učne uspešnosti je bila uporabljena 8-stopenjska lestvica samoporočanja o ocenah, in sicer so udeleženci in udeleženke odgovarjali na vprašanje »Kakšne ocene dobivaš na fakulteti? « (1 = večinoma slabše od zadostnih (5); 8 = večinoma odlične (10)).

Kazalniki pozitivnega razvoja mladih. Za merjenje kazalnikov pozitivnega razvoja mladih je bil uporabljen Vprašalnik pozitivnega razvoja mladih (Positive Youth Development Questionnaire (Geldhof et al., 2014), ki je sestavljen iz 34 postavk na 5 -stopenjski lestvici ( $1=$ močno se ne strinjam; 5 = močno se strinjam). Postavke merijo kazalnike pozitivnega razvoja mladih: kompetentnost (npr. »Pri šolskem delu sem uspešen.«), samozavest (npr. »Ne glede na vse, sem vesel, da sem takšen kot sem.«), skrb (npr. »Ko vidim koga, ki trpi ali mu je težko, se mi smili.«), karakter (npr. »Skoraj nikoli ne naredim stvari, za katere vem, da jih ne bi smel.«) in povezanost (npr. »Moji prijatelji skrbijo zame.«). Koeficienti zanesljivosti so pokazali, da je vprašalnik po posameznih komponentah psihometrično ustrezen: kompetentnost $(\alpha=0,70)$, samozavest $(\alpha=0,89)$, karakter $(\alpha=0,71)$, skrb $(\alpha$ $=0,80)$ in povezanost $(\alpha=0,78)$.

Medvrstniško nasilje. Izvajanje in doživljanje medvrstniškega nasilja smo merili z Vprašalnikom odnosov z vrstniki: nasilnež/žrtev (APRI-BT, Marsh et al., 2011), ki meri medvrstniško nasilje in viktimizacijo v verbalnih, fizičnih in odnosnih poddimenzijah. Vprašalnik je sestavljen iz 36 postavk in je razdeljen na dva dela, izvajanje in doživljanje medvrstniškega nasilja $\mathrm{z} 18$ postavkami v vsakem delu na 6 -stopenjski lestvici (od $1=$ nikoli do 6 = vsak dan). Za namen pričujoče raziskave so bile uporabljene poddimenzije, ki merijo besedno in odnosno izvajanje oziroma doživljanja nasilja. Prvi del je sestavljen iz postavk, ki preverjajo izvajanje nasilja, kjer posameznik oceni pogostost izvajanja medvrstniškega nasilja (npr. »norčeval/a sem se iz študenta/ke, tako da sem ga/jo zmerjal/a oz. žalil/a « za besedno nasilje in »obrnil/a prijatelje proti študentu/ki« za odnosno nasilje). Drugi del je sestavljen iz postavk, ki merijo pogostost doživljanja nasilja (npr. »študent/ka je imel/a o meni nesramne pripombe« za besedno doživljanje nasilja in »je študent/ka svoje prijatelje obrnil/a proti meni« za odnosno doživljanje nasilja). Zanesljivosti lestvic, ki sta merili pojavnost izvajanja nasilja, 
sta mejni (besedno nasilje: $\alpha=0,69$, odnosno nasilje: $\alpha=0,68$ ), medtem ko sta zanesljivosti obeh lestvic, ki ste merili doživljanje nasilja zelo dobri (besedna viktimizacija: $\alpha=0,87$, odnosna viktimizacija: $\alpha=0,90$ ).

\section{Postopek in statistična obdelava podatkov}

Podatki so bili zbrani v mesecih februarju, marcu in aprilu 2020. Podatki so bili najprej delno zbrani preko metode papir-svinčnik v sklopu predavanj oziroma seminarskih vaj pri predmetih na fakultetah $(n=177)$, zaradi pričetka pandemije se je zbiranje podatkov preselilo $\mathrm{v}$ spletno okolje na portal $1 \mathrm{ka}(n=187)$. Udeleženci so bili seznanjeni $\mathrm{z}$ namenom raziskave, prav tako so lahko kadarkoli prekinili s sodelovanjem.

Najprej smo izračunali deskriptivno statistiko (povprečje in standardni odklon) ter korelacije med posameznimi spremenljivkami. Nadalje smo preverili frekvence odgovorov udeležencev pri posameznih postavkah pri vsaki obliki izvajanja in doživljanja medvrstniškega nasilja. Za preverjanje napovedne vrednosti posameznih spremenljivk je bila v programu IBM SPSS Statistics 27 uporabljena hierarhična regresijska analiza, kjer so bili v prvem koraku vključeni naslednji dejavniki: spol, starost in učna uspešnost, saj raziskave kažejo, da predvsem spol igra pomembno vlogo pri napovedovanju izvajanja oziroma doživljanja medvrstniškega nasilja. V drugem koraku so bili vključeni kazalniki pozitivnega razvoja mladih.

\section{Rezultati}

V tabeli 22 je predstavljena deskriptivna statistika ter korelacije med preverjanimi konstrukti. Povprečne vrednosti kažejo na to, da se obe obliki izvajanja nasilja pojavljata v manjši meri, podobno velja tudi za viktimizacijo. Korelacije med posameznimi konstrukti kažejo, da moški v večji meri izvajajo in doživljajo besedno nasilje. Vse oblike nasilja in viktimizacije med sabo korelirajo pozitivno in statistično značilno. Izmed kazalnikov pozitivnega razvoja mladih se zgolj skrb negativno povezuje $\mathrm{z}$ obema oblikama nasilja, medtem ko karakter negativno korelira zgolj z besedno obliko nasilja. Povezanost se negativno povezuje $\mathrm{z}$ obema oblikama viktimizacije, pri čemer sta z odnosno viktimizacijo negativno korelirani tudi kompetentnost in samozavest. 
Tabela 22: Deskriptivna statistika in korelacije

\begin{tabular}{|c|c|c|c|c|c|c|c|c|c|c|c|c|c|}
\hline & M & SD & 1. & 2. & 3. & 4. & 5. & 6. & 7. & 8. & 9. & 10. & 11. \\
\hline 1. Spol & I & I & & & & & & & & & & & \\
\hline 2 Starost & 22,21 & 2,20 & $-0,10$ & & & & & & & & & & \\
\hline $\begin{array}{l}\text { 3. Učna } \\
\text { uspešnost }\end{array}$ & 6,08 & 1,14 & $0,17^{* *}$ & $0,20^{* *}$ & & & & & & & & & \\
\hline $\begin{array}{l}\text { 4. Besedno } \\
\text { nasilje }\end{array}$ & 1,29 & 0,42 & $-0,32^{* *}$ & $-0,12^{*}$ & $-0,07$ & & & & & & & & \\
\hline $\begin{array}{l}\text { 5. Odnos- } \\
\text { no nasilje }\end{array}$ & 1,12 & 0,26 & $-0,06$ & $-0,04$ & $-0,03$ & $0,44^{* *}$ & & & & & & & \\
\hline $\begin{array}{l}\text { 6. Besedna } \\
\text { viktimiza- } \\
\text { cija }\end{array}$ & 1,23 & 0,53 & $-0,13^{*}$ & 0,00 & $-0,01$ & $0,34^{* *}$ & $0,30^{* *}$ & & & & & & \\
\hline $\begin{array}{l}\text { 7. Odno- } \\
\text { sna vikti- } \\
\text { mizacija }\end{array}$ & 1,17 & 0,46 & 0,04 & $-0,02$ & $-0,01$ & $0,17^{* *}$ & $0,31^{* *}$ & $0,68^{* *}$ & & & & & \\
\hline $\begin{array}{l}\text { 8. Kompe- } \\
\text { tentnost }\end{array}$ & 3,32 & 0,59 & $-0,11^{*}$ & $0,14^{* *}$ & $0,18^{* *}$ & 0,02 & $-0,03$ & $-0,09$ & $-0,16^{* *}$ & & & & \\
\hline $\begin{array}{l}\text { 9. Samoza- } \\
\text { vest }\end{array}$ & 3,72 & 0,70 & $-0,07$ & $0,11^{*}$ & $0,16^{* *}$ & 0,03 & $-0,06$ & $-0,09$ & $-0,16^{* *}$ & $0,62^{* *}$ & & & \\
\hline $\begin{array}{l}\text { 10. Karak- } \\
\text { ter }\end{array}$ & 4,01 & 0,45 & 0,07 & $-0,06$ & 0,06 & $-0,11^{*}$ & $-0,09$ & 0,02 & $-0,04$ & $0,21^{* *}$ & $0,23^{* *}$ & & \\
\hline 11. Skrb & 4,12 & 0,60 & $0,17^{* *}$ & 0,00 & 0,05 & $-0,19^{*}$ & $-0,15^{* *}$ & $-0,06$ & $-0,02$ & $0,15^{* *}$ & $0,11^{*}$ & $0,49^{* *}$ & \\
\hline $\begin{array}{l}\text { 12. Pove- } \\
\text { zanost }\end{array}$ & 3,75 & 0,59 & $-0,03$ & 0,03 & $0,16^{* *}$ & $-0,06$ & 0,00 & $-0,16^{* *}$ & $-0,20^{* *}$ & $0,53^{* *}$ & $0,44^{* *}$ & $0,29^{* *}$ & $0,16^{* *}$ \\
\hline
\end{tabular}

Opombe. ${ }^{*} \mathrm{p}<0,05,{ }^{* *} \mathrm{p}<0,001$.

$\mathrm{V}$ tabeli 23 in 24 so predstavljene frekvence odgovorov na posamezne postavke, ki merijo izvajanje oziroma doživljanje besednega in odnosnega nasilja. Iz tabele 23 je razvidno, da je pri vsaki postavki večina udeležencev poročala, da ne izvajajo posamezne oblike nasilja. Pri tem nekoliko izstopajo naslednje oblike izvajanja besednega nasilja: zafrkavanje študentov, saj je 10,7 \% udeležencev poročalo, da so vsaj enkrat ali dvakrat na mesec zafrkavali študente, in podajanje nesramnih pripomb o študentu/ki, saj je 12,9\% udeležencev poročalo, da so vsaj enkrat ali dvakrat na mesec imeli nesramne pripombe o študentu/ki. 
Tabela 23: Frekvence odgovorov na posamezne postavke, ki merijo besedno in odnosno nasilje $(\mathrm{N}=364)$.

\begin{tabular}{|c|c|c|c|c|c|c|}
\hline & Nikoli & Redko & $\begin{array}{l}\text { Enkrat } \\
\text { ali dvak- } \\
\text { rat na } \\
\text { mesec }\end{array}$ & $\begin{array}{c}\text { Enkrat } \\
\text { na teden }\end{array}$ & $\begin{array}{l}\text { Nekaj- } \\
\text { krat na } \\
\text { teden }\end{array}$ & Vsak dan \\
\hline \multicolumn{7}{|l|}{ V tem študijskem letu sem ... } \\
\hline ... zafrkaval/-a študente. (B) & $\begin{array}{c}268 \\
(73,6 \%)\end{array}$ & $\begin{array}{c}57 \\
(15,7 \%)\end{array}$ & $\begin{array}{c}20 \\
(5,5 \%)\end{array}$ & $\begin{array}{c}6 \\
(1,6 \%)\end{array}$ & $\begin{array}{c}8 \\
(2,2 \%)\end{array}$ & $\begin{array}{c}5 \\
(1,4 \%)\end{array}$ \\
\hline $\begin{array}{l}\text {.... imel/a nesramne pripombe } \\
\text { o študentu/ki. (B) }\end{array}$ & $\begin{array}{c}202 \\
(55,5 \%)\end{array}$ & $\begin{array}{c}115 \\
(31,6 \%)\end{array}$ & $\begin{array}{c}30 \\
(8,2 \%)\end{array}$ & $\begin{array}{c}6 \\
(1,6 \%)\end{array}$ & $\begin{array}{c}10 \\
(2,7 \%)\end{array}$ & $\begin{array}{c}1 \\
(0,3 \%)\end{array}$ \\
\hline $\begin{array}{l}\text {... se norčeval/a iz študenta/ } \\
\text { ke. (B) }\end{array}$ & $\begin{array}{c}255 \\
(70,2 \%)\end{array}$ & $\begin{array}{c}83 \\
(22,9 \%)\end{array}$ & $\begin{array}{c}15 \\
(4,1 \%)\end{array}$ & $\begin{array}{c}6 \\
(1,7 \%)\end{array}$ & $\begin{array}{c}3 \\
(0,8 \%)\end{array}$ & $\begin{array}{c}1 \\
(0,3 \%)\end{array}$ \\
\hline $\begin{array}{l}\text {... se spravil/a na študenta/ko } \\
\text { s kletvicami. (B) }\end{array}$ & $\begin{array}{c}339 \\
(93,4 \%)\end{array}$ & $\begin{array}{c}17 \\
(4,7 \%)\end{array}$ & $\begin{array}{c}6 \\
(1,7 \%)\end{array}$ & l & $\begin{array}{c}1 \\
(0,3 \%)\end{array}$ & I \\
\hline $\begin{array}{l}\text {... rekel/la študentom stvari } \\
\text { o njihovem izgledu, ki so jih } \\
\text { prizadele. (B) }\end{array}$ & $\begin{array}{c}344 \\
(94,5 \%)\end{array}$ & $\begin{array}{c}15 \\
(4,1 \%)\end{array}$ & $\begin{array}{c}2 \\
(0,5 \%)\end{array}$ & $\begin{array}{c}1 \\
(0,3 \%)\end{array}$ & I & l \\
\hline $\begin{array}{l}\text {... se norčeval/a iz študenta/ } \\
\text { ke, tako da sem ga/jo zmer- } \\
\text { jal/a oz. žalil/a. (B) }\end{array}$ & $\begin{array}{c}352 \\
(96,7 \%)\end{array}$ & $\begin{array}{c}8 \\
(2,2 \%)\end{array}$ & $\begin{array}{c}1 \\
(0,3 \%)\end{array}$ & $\begin{array}{c}2 \\
(0,5 \%)\end{array}$ & l & l \\
\hline $\begin{array}{l}\text {... obrnil/a prijatelje proti štu- } \\
\text { dentu/ki. (O) }\end{array}$ & $\begin{array}{c}332 \\
(91,8 \%)\end{array}$ & $\begin{array}{c}25 \\
(6,9 \%)\end{array}$ & $\begin{array}{c}4 \\
(1,1 \%)\end{array}$ & $\begin{array}{c}1 \\
(0,3 \%)\end{array}$ & l & l \\
\hline $\begin{array}{l}\text {... svojim prijateljem pove- } \\
\text { dal/a stvari o študentu/ki z } \\
\text { namenom, da bi ga/jo spra- } \\
\text { vil/a v težave. (O) }\end{array}$ & $\begin{array}{c}342 \\
(94,0 \%)\end{array}$ & $\begin{array}{c}18 \\
(4,9 \%)\end{array}$ & $\begin{array}{c}4 \\
(1,1 \%)\end{array}$ & l & I & l \\
\hline $\begin{array}{l}\text {... spodbujal/a študente k šir- } \\
\text { jenju govoric o drugem/drugi } \\
\text { študentu/ki. (O) }\end{array}$ & $\begin{array}{c}330 \\
(90,7 \%)\end{array}$ & $\begin{array}{c}29 \\
(8,0 \%)\end{array}$ & $\begin{array}{c}4 \\
(1,1 \%)\end{array}$ & $\begin{array}{c}1 \\
(0,3 \%)\end{array}$ & l & l \\
\hline $\begin{array}{l}\text {... spodbujal/a študentu, da so } \\
\text { ignorirali druge/ga študen- } \\
\text { ta/ko. (O) }\end{array}$ & $\begin{array}{c}330 \\
(90,7 \%)\end{array}$ & $\begin{array}{c}29 \\
(8,0 \%)\end{array}$ & $\begin{array}{c}4 \\
(1,1 \%)\end{array}$ & $\begin{array}{c}1 \\
(0,3 \%)\end{array}$ & / & l \\
\hline $\begin{array}{l}\text {... študenta/ko namerno iz- } \\
\text { ključil/a iz aktivnosti. (O) }\end{array}$ & $\begin{array}{c}336 \\
(92,3 \%)\end{array}$ & $\begin{array}{c}21 \\
(5,8 \%)\end{array}$ & $\begin{array}{c}3 \\
(0,8 \%)\end{array}$ & $\begin{array}{c}2 \\
(0,5 \%)\end{array}$ & I & l \\
\hline $\begin{array}{l}\text {.. z neprijaznim pogledom } \\
\text { odgnal/a študente od sebe. } \\
\text { (O) }\end{array}$ & $\begin{array}{c}273 \\
(75,0 \%)\end{array}$ & $\begin{array}{c}68 \\
(18,7 \%)\end{array}$ & $\begin{array}{c}15 \\
(4,1 \%)\end{array}$ & $\begin{array}{c}6 \\
(1,6 \%)\end{array}$ & $\begin{array}{c}2 \\
(0,5 \%)\end{array}$ & l \\
\hline
\end{tabular}

Opombe: $\mathrm{B}$ - besedno nasilje, $\mathrm{O}$ - odnosno nasilje

$\mathrm{V}$ tabeli 24 so predstavljene frekvence odgovorov postavk, ki merijo besedno in odnosno viktimizacijo. Podobno kot pri izvajanju nasilja je tudi pri doživljanju nasilja večina udeležencev poročala, da ne doživlja besednega oziroma odnosnega nasilja. Prav tako tudi pri poročanju o doživljanju nasilja izstopata postavki o doživljanju besednega nasilja, ki se nanaša na poročanje o norčevanju (8,o \% udeležencev je poročalo, da se vsaj enkrat ali 
dvakrat na mesec drugi norčujejo iz njih). Pri poročanju o doživljanju odnosnega nasilja izstopa ignoriranje s strani študentov/k, ko so bili s svojimi prijatelji $(8,7 \%$ udeležencev je poročalo, da se vsaj enkrat ali dvakrat na mesec zgodi, da jih študenti ignorirajo, ko so s svojimi prijatelji).

Tabela 24: Frekvence odgovorov na posamezne postavke, ki merijo besedno in odnosno viktimizacijo $(\mathrm{N}=364)$.

\begin{tabular}{|c|c|c|c|c|c|c|}
\hline & Nikoli & Redko & $\begin{array}{l}\text { Enkrat } \\
\text { ali dvak- } \\
\text { rat na } \\
\text { mesec }\end{array}$ & $\begin{array}{c}\text { Enkrat } \\
\text { na teden }\end{array}$ & $\begin{array}{l}\text { Nekaj- } \\
\text { krat na } \\
\text { teden }\end{array}$ & Vsak dan \\
\hline \multicolumn{7}{|l|}{ V tem študijskem letu ... } \\
\hline $\begin{array}{l}\text {... so se študenti norčevali iz } \\
\text { mene. (B) }\end{array}$ & $\begin{array}{c}271 \\
(74,5 \%)\end{array}$ & $\begin{array}{c}64 \\
(17,6 \%) \\
\end{array}$ & $\begin{array}{c}14 \\
(3,8 \%)\end{array}$ & $\begin{array}{c}7 \\
(1,9 \%)\end{array}$ & $\begin{array}{c}4 \\
(1,1 \%)\end{array}$ & $\begin{array}{c}4 \\
(1,1 \%) \\
\end{array}$ \\
\hline $\begin{array}{l}\text {.... je študent/ka imel/a o } \\
\text { meni nesramne pripombe. (B) }\end{array}$ & $\begin{array}{c}275 \\
(75,5 \%)\end{array}$ & $\begin{array}{c}68 \\
(18,7 \%)\end{array}$ & $\begin{array}{c}9 \\
(2,5 \%)\end{array}$ & $\begin{array}{c}7 \\
(1,9 \%)\end{array}$ & $\begin{array}{c}4 \\
(1,1 \%)\end{array}$ & $\begin{array}{c}1 \\
(0,3 \%)\end{array}$ \\
\hline $\begin{array}{l}\ldots \text { so si študenti o meni izmis- } \\
\text { lili šale. (B) }\end{array}$ & $\begin{array}{c}316 \\
(86,8 \%)\end{array}$ & $\begin{array}{c}29 \\
(8,0 \%)\end{array}$ & $\begin{array}{c}10 \\
(2,7 \%)\end{array}$ & $\begin{array}{c}4 \\
(1,1 \%)\end{array}$ & $\begin{array}{c}3 \\
(0,8 \%)\end{array}$ & $\begin{array}{c}2 \\
(0,5 \%)\end{array}$ \\
\hline $\begin{array}{l}\text {... so študenti komentirali moj } \\
\text { videz na način, ki me je pri- } \\
\text { zadel. (B) }\end{array}$ & $\begin{array}{c}314 \\
(86,3 \%)\end{array}$ & $\begin{array}{c}38 \\
(10,4 \%)\end{array}$ & $\begin{array}{c}6 \\
(1,6 \%)\end{array}$ & $\begin{array}{c}3 \\
(0,8 \%)\end{array}$ & $\begin{array}{c}2 \\
(0,5 \%)\end{array}$ & $\begin{array}{c}1 \\
(0,3 \%)\end{array}$ \\
\hline $\begin{array}{l}\ldots \text { so se mi študenti posmeho- } \\
\text { vali. (B) }\end{array}$ & $\begin{array}{c}326 \\
(89,6 \%)\end{array}$ & $\begin{array}{c}31 \\
(8,5 \%)\end{array}$ & $\begin{array}{c}3 \\
(0,8 \%)\end{array}$ & $\begin{array}{c}2 \\
(0,5 \%)\end{array}$ & l & $\begin{array}{c}2 \\
(0,5 \%)\end{array}$ \\
\hline $\begin{array}{l}\text {... so mi študenti dajali nesra- } \\
\text { mne vzdevke. (B) }\end{array}$ & $\begin{array}{c}347 \\
(95,3 \%)\end{array}$ & $\begin{array}{c}13 \\
(3,6 \%)\end{array}$ & $\begin{array}{c}1 \\
(0,3 \%)\end{array}$ & $\begin{array}{c}1 \\
(0,3 \%)\end{array}$ & I & $\begin{array}{c}1 \\
(0,3 \%)\end{array}$ \\
\hline $\begin{array}{l}\text {... študent/ka ni želel/a biti } \\
\text { moj/a prijatelj/ica, ker me } \\
\text { drugi niso marali. (O) }\end{array}$ & $\begin{array}{c}327 \\
(89,8 \%)\end{array}$ & $\begin{array}{c}26 \\
(7,1 \%)\end{array}$ & $\begin{array}{c}8 \\
(2,2 \%)\end{array}$ & $\begin{array}{c}2 \\
(0,5 \%)\end{array}$ & I & $\begin{array}{c}1 \\
(0,3 \%)\end{array}$ \\
\hline $\begin{array}{l}\text {... me je študent/ka ignori- } \\
\text { ral/a, ko je bil/a s svojimi pri- } \\
\text { jatelji. (O) }\end{array}$ & $\begin{array}{c}292 \\
(80,2 \%)\end{array}$ & $\begin{array}{c}44 \\
(12,1 \%)\end{array}$ & $\begin{array}{c}16 \\
(4,4 \%)\end{array}$ & $\begin{array}{c}3 \\
(0,8 \%)\end{array}$ & $\begin{array}{c}6 \\
(1,6 \%)\end{array}$ & $\begin{array}{c}3 \\
(0,8 \%)\end{array}$ \\
\hline $\begin{array}{l}\text {... je študent/ka svoje prijate- } \\
\text { lje obrnil/a proti meni. (O) }\end{array}$ & $\begin{array}{c}335 \\
(92,0 \%)\end{array}$ & $\begin{array}{c}20 \\
(5,5 \%)\end{array}$ & $\begin{array}{c}2 \\
(0,5 \%)\end{array}$ & $\begin{array}{c}3 \\
(0,8 \%)\end{array}$ & $\begin{array}{c}2 \\
(0,5 \%)\end{array}$ & $\begin{array}{c}2 \\
(0,5 \%)\end{array}$ \\
\hline $\begin{array}{l}\ldots \text { nisem bil/a povabljen/a } \mathrm{k} \\
\text { študentu/ki, ker me ostali ne } \\
\text { marajo. }(\mathrm{O})\end{array}$ & $\begin{array}{c}340 \\
(93,4 \%)\end{array}$ & $\begin{array}{c}13 \\
(3,6 \%)\end{array}$ & $\begin{array}{c}6 \\
(1,6 \%)\end{array}$ & $\begin{array}{c}3 \\
(0,8 \%)\end{array}$ & I & $\begin{array}{c}2 \\
(0,5 \%)\end{array}$ \\
\hline $\begin{array}{l}\text {... je študent/ka spodbujal/a } \\
\text { ostale, da so o meni sprožili } \\
\text { govorice. (O) }\end{array}$ & $\begin{array}{c}334 \\
(91,8 \%)\end{array}$ & $\begin{array}{c}17 \\
(4,7 \%)\end{array}$ & $\begin{array}{c}8 \\
(2,2 \%)\end{array}$ & $\begin{array}{c}3 \\
(0,8 \%)\end{array}$ & I & $\begin{array}{c}2 \\
(0,5 \%)\end{array}$ \\
\hline $\begin{array}{l}\text {... so me študenti namerno iz- } \\
\text { ključili iz aktivnosti. }(\mathrm{O})\end{array}$ & $\begin{array}{c}333 \\
(91,5 \%)\end{array}$ & $\begin{array}{c}23 \\
(6,3 \%)\end{array}$ & $\begin{array}{c}4 \\
(1,1 \%)\end{array}$ & $\begin{array}{c}2 \\
(0,5 \%)\end{array}$ & I & $\begin{array}{c}2 \\
(0,5 \%)\end{array}$ \\
\hline
\end{tabular}

Opombe: $\mathrm{B}$ - besedna viktimizacija, $\mathrm{O}$ - odnosna viktimizacija

Iz tabele 25 je razvidna hierarhična regresijska analiza za spremenljivke, ki napovedujejo izvajanje besednega nasilja. Demografske spremenljivke, ki so bile vključene v prvem koraku, pojasnijo $12 \%$ variance, pri čemer 
sta spol in starost statistično značilna negativna napovednika izvajanja besednega nasilja, kar pomeni, da moški in mlajši udeleženci v večji meri izvajajo besedno nasilje kot ženske udeleženke oziroma starejši udeleženci raziskave. $V$ drugem koraku so bili vključeni kazalniki pozitivnega razvoja mladih, ki dodatno pojasnijo $4 \%$ variance izvajanja besednega nasilja. Izmed vseh vključenih spremenljivk je zgolj skrb statistično značilen napovednik izvajanja besednega nasilja, in sicer so udeleženci, ki so poročali o višji stopnji skrbi, v manjši meri izvajalci besednega nasilja. Vse vključene spremenljivke pojasnijo $16 \%$ variance izvajanja besednega nasilja.

Tabela 25: Hierarhična multipla regresijska analiza za spremenljivke, ki napovedujejo izvajanje besednega nasilja

\begin{tabular}{|cccccc}
\multicolumn{5}{c}{ Besedno nasilje } \\
\cline { 2 - 6 } & Model 1 & Model 2 \\
\hline B & & $\beta$ & B & $\beta$
\end{tabular}

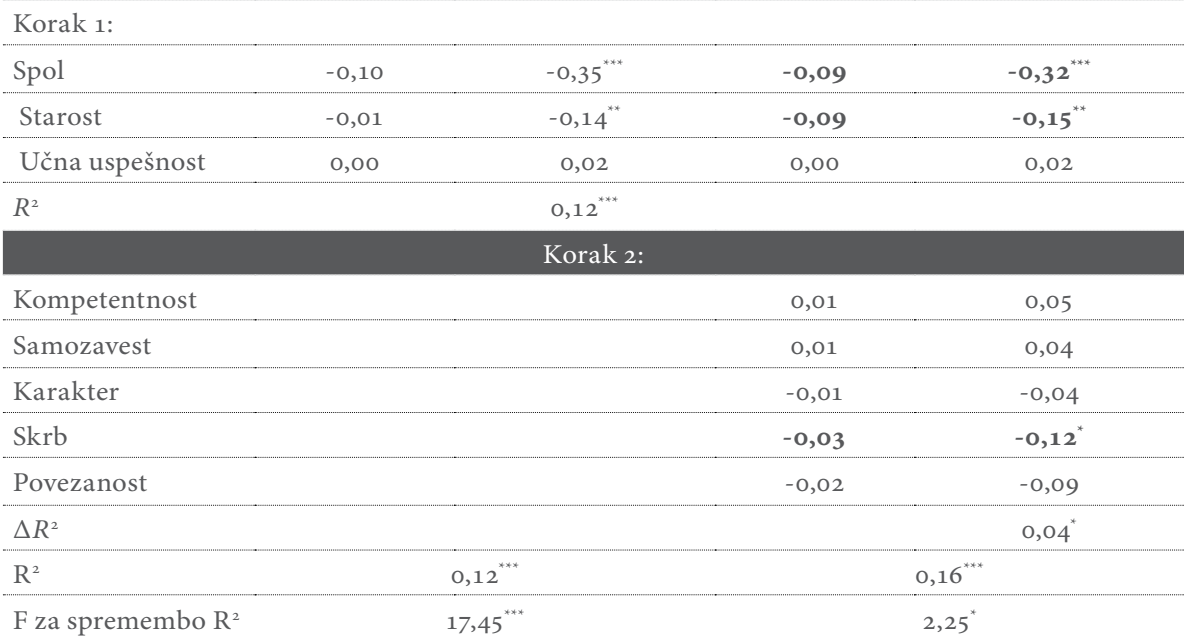

Opombe: ${ }^{*} \mathrm{p}<0,05,{ }^{* *} \mathrm{p}<0,0 \mathrm{I},{ }^{* * *} \mathrm{p}<0,00 \mathrm{I}$.

$\mathrm{V}$ tabeli 26 je predstavljena hierarhična regresijska analiza za spremenljivke, ki napovedujejo izvajanje odnosnega nasilja. Rezultati kažejo, da demografske spremenljivke ne napovedujejo izvajanja odnosnega nasilja, medtem ko je iz drugega koraka razvidno, da udeleženci, ki so poročali o višji stopnji skrbi, poročajo o nižji stopnji izvajanja odnosnega nasilja. 
Tabela 26: Hierarhična multipla regresijska analiza za spremenljivke, ki napovedujejo izvajanja odnosnega nasilja

\begin{tabular}{|c|c|c|c|c|}
\hline & \multicolumn{4}{|c|}{ Odnosno nasilje } \\
\hline & \multicolumn{2}{|c|}{ Model 1} & \multicolumn{2}{|c|}{ Model 2} \\
\hline & $\mathrm{B}$ & $\beta$ & $\mathrm{B}$ & $\beta$ \\
\hline \multicolumn{5}{|c|}{ Korak 1: } \\
\hline Spol & $-0,01$ & $-0,06$ & $-0,01$ & $-0,03$ \\
\hline Starost & 0,00 & $-0,05$ & 0,00 & $-0,04$ \\
\hline Učna uspešnost & 0,00 & $-0,01$ & 0,00 & $-0,01$ \\
\hline \multicolumn{5}{|c|}{0,01} \\
\hline \multicolumn{5}{|c|}{ Korak 2: } \\
\hline Kompetentnost & & & 0,00 & 0,01 \\
\hline Samozavest & & & $-0,01$ & $-0,07$ \\
\hline Karakter & & & 0,00 & $-0,02$ \\
\hline Skrb & & & $-0,02$ & $-0,14$ \\
\hline Povezanost & & & 0,01 & 0,05 \\
\hline$\Delta R^{2}$ & & & & $0,03^{*}$ \\
\hline $\mathrm{R}^{2}$ & \multicolumn{2}{|c|}{0,01} & \multicolumn{2}{|c|}{0,03} \\
\hline F za spremembo $\mathrm{R}^{2}$ & \multicolumn{2}{|c|}{0,66} & \multicolumn{2}{|c|}{1,28} \\
\hline
\end{tabular}

Opombe: ${ }^{*} \mathrm{p}<0,05,{ }^{* *} \mathrm{p}<0,0 \mathrm{I},{ }^{* * *} \mathrm{p}<0,00 \mathrm{I}$

Iz tabele 27 je razvidna hierarhična regresijska analiza za spremenljivke, ki napovedujejo besedno viktimizacijo. V prvem koraku, v katerem so bile vključene demografske spremenljivke, se je zgolj spol izkazal kot statistično značilen napovednik besedne viktimizacije. Podobno kot pri besednem nasilju, so tudi v tem primeru moški tisti, ki poročajo o višji stopnji besedne viktimizacije. Demografske spremenljivke so pojasnile $2 \%$ variance besedne viktimizacije. V drugem koraku so bili vključeni kazalniki pozitivnega razvoja mladih, med katerimi je bila zgolj povezanost statistično značilen napovednik besedne viktimizacije, kar pomeni, da so tisti udeleženci, ki poročajo, da so bolj povezani z vrstniki, starši, fakulteto in socialno skupnostjo, v manjši meri žrtve besednega nasilja. Skupno vključene spremenljivke pojasnijo $6 \%$ variance odnosnega nasilja. 
Tabela 27: Hierarhična multipla regresijska analiza za spremenljivke, ki napovedujejo besedno viktimizacijo

\begin{tabular}{|c|c|c|c|c|}
\hline & \multicolumn{4}{|c|}{ Besedna viktimizacija } \\
\hline & \multicolumn{2}{|c|}{ Model 1} & \multicolumn{2}{|c|}{ Model 2} \\
\hline & $\mathrm{B}$ & $\beta$ & B & $\beta$ \\
\hline \multicolumn{5}{|c|}{ Korak 1: } \\
\hline Spol & $-0,04$ & $-0,13^{*}$ & $-0,04$ & $-0,14^{* *}$ \\
\hline Starost & 0,00 & $-0,02$ & 0,00 & $-0,02$ \\
\hline Učna uspešnost & 0,01 & 0,01 & 0,01 & 0,05 \\
\hline \multicolumn{5}{|c|}{0,02} \\
\hline \multicolumn{5}{|c|}{ Korak 2: } \\
\hline Kompetentnost & & & 0,00 & $-0,02$ \\
\hline Samozavest & & & $-0,01$ & $-0,04$ \\
\hline Karakter & & & 0,03 & 0,12 \\
\hline Skrb & & & $-0,01$ & $-0,05$ \\
\hline Povezanost & & & $-0,04$ & $-0,17^{* *}$ \\
\hline$\Delta R^{2}$ & & & & $0,04^{*}$ \\
\hline $\mathrm{R}^{2}$ & \multicolumn{2}{|c|}{0,02} & \multicolumn{2}{|c|}{$0,06^{*}$} \\
\hline F za spremembo $\mathrm{R}^{2}$ & \multicolumn{2}{|c|}{2,04} & \multicolumn{2}{|c|}{$2,85^{*}$} \\
\hline
\end{tabular}

Opombe: ${ }^{*} \mathrm{p}<0,05,{ }^{* *} \mathrm{p}<0,0 \mathrm{I},{ }^{* * *} \mathrm{p}<0,00 \mathrm{I}$.

V tabeli 28 je predstavljena hierarhična regresijska analiza za spremenljivke, ki napovedujejo odnosno viktimizacijo. Demografske spremenljivke, ki so bile vključene v prvi korak, niso statistično značilni napovedniki odnosne viktimizacije. Izmed kazalnikov pozitivnega razvoja mladih, ki so bili vključeni v drugem koraku, je bila samo povezanost statistično značilen napovednik kazalnikov pozitivnega razvoja mladih. Udeleženci z višjo stopnjo povezanosti so namreč v manjši meri žrtve odnosnega nasilja. Vse spremenljivke pojasnijo $5 \%$ variance odnosne viktimizacije. 
Tabela 28: Hierarhična multipla regresijska analiza za spremenljivke, ki napovedujejo odnosno viktimizacijo

\begin{tabular}{|c|c|c|c|c|}
\hline & \multicolumn{4}{|c|}{ Odnosna viktimizacija } \\
\hline & \multicolumn{2}{|c|}{ Model 1} & \multicolumn{2}{|c|}{ Model 2} \\
\hline & B & $\beta$ & B & $\beta$ \\
\hline \multicolumn{5}{|c|}{ Korak 1: } \\
\hline Spol & 0,01 & 0,04 & 0,01 & 0,02 \\
\hline Starost & 0,00 & $-0,02$ & 0,00 & $-0,01$ \\
\hline Učna uspešnost & 0,00 & $-0,01$ & 0,00 & 0,03 \\
\hline$R^{2}$ & & \multicolumn{2}{|l|}{0,00} & \\
\hline \multicolumn{5}{|c|}{ Korak 2: } \\
\hline Kompetentnost & & & $-0,01$ & $-0,04$ \\
\hline Samozavest & & & $-0,01$ & $-0,08$ \\
\hline Karakter & & & 0,01 & 0,03 \\
\hline Skrb & & & 0,00 & 0,00 \\
\hline Povezanost & & & $-0,03$ & $-0,15^{* *}$ \\
\hline$\Delta R^{2}$ & & & & $0,05^{* *}$ \\
\hline $\mathrm{R}^{2}$ & \multicolumn{2}{|c|}{0,00} & \multicolumn{2}{|c|}{$0,05^{*}$} \\
\hline F za spremembo $\mathrm{R}^{2}$ & \multicolumn{2}{|c|}{0,26} & \multicolumn{2}{|c|}{$3,46^{* *}$} \\
\hline
\end{tabular}

Opombe: ${ }^{*} \mathrm{p}<0,0,,^{* *} \mathrm{p}<0,0 \mathrm{I},{ }^{* * *} \mathrm{p}<0,00 \mathrm{I}$

\section{Diskusija}

Namen prispevka je bil preveriti pojavnost izvajanja in doživljanja medvrstniškega nasilja med študenti in študentkami v slovenskem prostoru ter napovedno vrednost demografskih spremenljivk in kazalnikov pozitivnega razvoja mladih. Rezultati so pokazali, da se tako izvajanje kot doživljanje nasilja pri študentkah in študentih pojavlja $\mathrm{v}$ manjši meri, a vendar je o izvajanju oziroma doživljanju enega izmed nasilnih dejanj poročala približno desetina udeležencev. Rezultati hierarhične regresijske analize so pokazali, da je spol statistično značilen napovednik izvajanja in doživljanja besednega nasilja, medtem ko je starost statistično značilen napovednik zgolj izvajanja besednega nasilja. Izmed kazalnikov pozitivnega razvoja mladih, se je skrb pokazala kot statistično značilen napovednik obeh oblik izvajanja nasilja, povezanost pa kot statistično značilen napovednik obeh oblik doživljanja nasilja. Ostali kazalniki pozitivnega razvoja mladih niso bili statistično značilni napovedniki izvajanja nasilja ali viktimizacije.

Splošno gledano so spol, starost, učna uspešnost in kazalniki pozitivnega razvoja mladih pojasnili sorazmeroma nizko stopnjo variance izva- 
janja nasilja oziroma viktimizacije. To kaže na kompleksnost raziskovanja izvajanja in doživljanja medvrstniškega nasilja tudi v študentski populaciji. Moški so bili v večji meri izvajalci in žrtve besednega nasilja kot ženske, kar je skladno $\mathrm{z}$ rezultati študij iz obdobij osnovne in srednje šole (Wang et al., 2009). Predhodne raziskave, izvedene na vzorcu študentov, so pokazale, da so bili moški v večji meri izvajalci nasilja, večinoma pa ni bilo razlik med spoloma v doživljanju nasilja (Lund in Ross, 2016).

Rezultati jasno kažejo na pomembno vlogo skrbi za drugega pri preprečevanju izvajanja nasilnega vedenja. Nižja stopnja empatije se povezuje z neželenimi vedenji, kot je izvajanje nasilja (van Noorden et al., 2015), na kar kažejo tudi rezultati pričujoče raziskave. Vloga kognitivne empatije pa ni tako enoznačna, saj posamezne raziskave poročajo o negativni povezanosti med konstruktoma (Belacchi in Farina, 2012), medtem ko druge niso poročale o tem, da sta omenjena konstrukta povezana (Caravita et al., 2009).

Povezanost z vrstniki, univerzitetnim okoljem, starši in okolico je negativen napovednik doživljanja nasilja pri študentkah in študentih. Prijateljstvo, opora vrstnikov, opora staršev in opora učiteljev so se že na vzorcu mladostnikov pokazali kot varovalni dejavnik doživljanja nasilja (Košir et al., 2019; Stadler et al., 2010). Raziskovalci že dlje časa opozarjajo na socialno naravo nasilja (Salmivalli, 2010), saj se nasilje navadno dogaja $\mathrm{v}$ prisotnosti drugih, zato imajo opazovalci nasilja veliko vlogo pri tem fenomenu. Prav tako je pomembno, da imajo študenti in študentke vzpostavljeno socialno mrežo, saj jim bodo lahko njihovi prijatelji in prijateljice nudili oporo oziroma jih bodo branili pred nasilnim vedenjem drugih.

\section{Pomanjkljivosti raziskave, predlogi za pedagoško prakso in za nadaljnje raziskave}

Pričujoča raziskava je ena izmed prvih raziskav, ki je raziskovala pojavnost ter dejavnike medvrstniškega nasilja med študenti in študentkami v slovenskem prostoru, vendar ima kljub temu nekaj pomanjkljivosti. Vzorec je bil namreč zbran po metodi snežne kepe, prav tako se je sredi zbiranja podatkov zaradi pričetka epidemije spremenil način zbiranja podatkov. Pred epidemijo so študenti in študentke vprašalnike izpolnjevali v fizični obliki preko metode papir-svinčnik, po pričetku epidemije se je zbiranje podatkov preselilo v spletno okolje (portal 1ka), kar je lahko vplivalo na verodostojnost podatkov. Udeleženci so izpolnjevali vprašalnik medvrstniškega nasilja in viktimizacije, ki je bil zasnovan za uporabo v osnovnih in srednjih šolah ter je bil prilagojen študentski populaciji. Zaradi starostnih 
razlik je to lahko vplivalo na veljavnost rezultatov. Med udeleženci so prav tako izstopali študenti in študentke Univerze v Mariboru, zato vzorec študentov ni reprezentativen. Prav tako je zaradi prečnega raziskovalnega načrta nemogoče sklepati o vzročno-posledičnih odnosih.

Rezultati tega prispevka imajo tudi pomembno uporabno vrednost, saj nakazujejo, da je pomembno, da študentke in študenti tudi v času študija krepijo čustvene in socialne kompetence, med katere spadata skrb za druge ter povezanost z vrstniki, šolskim okoljem, starši in širšo skupnostjo. Pomen skrbi za druge, ki je negativen napovednik izvajanja nasilja, se lahko spodbuja med predavanji in obštudijskih vsebinah preko predstavitev študij primera, prikaza videov žrtev, analize čustev in misli žrtev ter spremembe bazičnih prepričanj izvajalcev nasilja (Del Rey et al., 2016). Za spodbujanje povezanosti študentk in študentov, ki lahko zmanjša pojavnost viktimizacije, so lahko uporabljene naslednje aktivnosti: vzpostavitev podpornih skupin, spodbujanje razvoja čustvenih in socialnih kompetenc študentk in študentov in spodbujanje udejstvovanja v obštudijskih dejavnostih na fakulteti in $\mathrm{v}$ mnogih društvih $\mathrm{z}$ namenom krepitve pripadnosti fakulteti ali spodbujanja povezanosti s študenti drugih študijskih smeri.

Medvrstniško nasilje med študenti in študentkami je v slovenskem prostoru premalo raziskano, zato bi bilo treba $\mathrm{v}$ prihodnje raziskave vključiti reprezentativni vzorec študentk in študentov, druge potencialne varovalne dejavnike (npr. stopnja nadzora čustev, prosocialno vedenje) ter raziskati pojavnost spletnega nasilja. Smiselno bi bilo zasnovati vprašalnik za merjenje medvrstniškega nasilja in viktimizacije posebej za študente in študentke, saj lahko pričakujemo, da pri njih prihaja do drugačnih nasilnih dejanj kot pri osnovnošolcih oziroma srednješolcih.

\section{Literatura}

Belacchi, Carmen in Eleonora Farina. 2012. "Feeling and Thinking of Others: Affective and Cognitive Empathy and Emotion Comprehension in Prosocial/Hostile Preschoolers." Aggressive Behavior 38 (2): 150-65.

Bowers, Edmond P., Yibing Li, Megan K. Kiely, Aerika Brittian, Jacqueline V. Lerner in Richard M. Lerner. 2010. “The Five Cs Model of Positive Youth Development: A Longitudinal Analysis of Confirmatory Factor Structure and Measurement Invariance." Journal of Youth and Adolescence 39 (7): 720-35. 
Caravita, Simona C.S., Paola Di Blasio in Christina Salmivalli. 20o9. "Unique and Interactive Effects of Empathy and Social Status on Involvement in Bullying." Social Development 18 (1): 140-63.

Curwen, Tracey, Jessica S McNichol in Glynn W Sharpe. 2011. “The Progression of Bullying from Elementary School to University.” International Journal of Humanities and Social Science 1 (13): 47-54.

Fredkove, Windy M., Amy L. Gower in Renee E. Sieving. 2019. “Association Among Internal Assets, Bullying, and Emotional Distress in Eighth Grade Students." Journal of School Health 89 (11): 883-89.

Geldhof, G. J., Edmond P. Bowers, Michelle J. Boyd, Megan K. Mueller, Christopher M. Napolitano, Kristina L. Schmid, Jacqueline V. Lerner in Richard M. Lerner. 2014. "Creation of Short and Very Short Measures of the Five Cs of Positive Youth Development." Journal of Research on Adolescence 24 (1): 163-76.

Hilliard, Lacey J., Edmond P. Bowers, Kathleen N. Greenman, Rachel M. Hershberg, G. John Geldhof, Samantha A. Glickman, Jacqueline V. Lerner in Richard M. Lerner. 2014. "Beyond the Deficit Model: Bullying and Trajectories of Character Virtues in Adolescence." Journal of Youth and Adolescence 43 (6): 991-1003.

Jelicic, Helena, Deborah L. Bobek, Erin Phelps, Richard M. Lerner in Jacqueline V. Lerner. 2007. “Using Positive Youth Development to Predict Contribution and Risk Behaviors in Early Adolescence: Findings from the First Two Waves of the 4-H Study of Positive Youth Development." International Journal of Behavioral Development 31 (3): 263-73.

Jenkins, Lyndsay N., Michelle Kilpatrick Demaray, Stephanie Secord Fredrick in Kelly Hodgson Summers. 2016. "Associations Among Middle School Students' Bullying Roles and Social Skills.” Journal of School Violence 15 (3): $259-78$.

Kendrick, Kristin, Göran Jutengren in Håkan Stattin. 2012. “The Protective Role of Supportive Friends against Bullying Perpetration and Victimization." Journal of Adolescence 35 (4): 1069-80.

Košir, Katja, Lucia Klasinc, Tanja Špes, Tina Pivec, Gašper Cankar in Marina Horvat. 2019. "Predictors of Self-Reported and Peer-Reported Victimization and Bullying Behavior in Early Adolescents : The Role of School, Classroom, and Individual Factors." European Journal of Psychology of Education, 1-22. 
Kowalski, Robin M. in Susan P. Limber. 2013. "Psychological, Physical, and Academic Correlates of Cyberbullying and Traditional Bullying." Journal of Adolescent Health 53 (1 SUPPL): S13-20.

Lewin-Bizan, Selva, Alicia Doyle Lynch, Kristen Fay, Kristina Schmid, Caitlin McPherran, Jacqueline V. Lerner in Richard M. Lerner. 2010. “Trajectories of Positive and Negative Behaviors from Early- to Middle-Adolescence." Journal of Youth and Adolescence 39 (7): 751-63.

Lund, Emily M. in Scott W. Ross. 2017. "Bullying Perpetration, Victimization, and Demographic Differences in College Students: A Review of the Literature." Trauma, Violence, and Abuse 18 (3): 348-6o.

Marsh, Herbert W., Benjamin Nagengast, Alexandre J. S. Morin, Roberto H. Parada, Rhonda G. Craven in Linda R. Hamilton. 2011. "Construct Validity of the Multidimensional Structure of Bullying and Victimization: An Application of Exploratory Structural Equation Modeling." Journal of Educational Psychology 103 (3): 701-32.

Moore, Sophie E., Rosana E. Norman, Shuichi Suetani, Hannah J. Thomas, Peter D. Sly in James G Scott. 2017. "Consequences of Bullying Victimization in Childhood and Adolescence: A Systematic Review and Meta-Analysis." World Journal of Psychiatry 7 (1): 60.

Murry, Velma M., Cady Berkel, Ronald L. Simons, Leslie G. Simons in Frederick X. Gibbons. 2014. "A Twelve-Year Longitudinal Analysis of Positive Youth Development among Rural African American Males.” Journal of Research on Adolescence 24 (3): 512-25.

Nansel, Tonja R., Wendy Craig, Mary D. Overpeck, Gitanjali Saluja in W. June Ruan. 2004. "Cross-National Consistency in the Relationship between Bullying Behaviors and Psychosocial Adjustment." Archives of Pediatrics and Adolescent Medicine 158 (8): 730-36.

Noorden, Tirza H. J. van, Gerbert J.T. Haselager, Antonius H.N. Cillessen in William M. Bukowski. 2015. "Empathy and Involvement in Bullying in Children and Adolescents: A Systematic Review." Journal of Youth and Adolescence 44 (3): 637-57.

Perry, Amelia D. in Sarai Blincoe. „Bullies and victims in higher education: a mixed-methods approach." Journal of Bullying and Social Aggression 1 (2015).

Pörhölä, Maili, Kristen Cvancara, Esta Kaal, Kristina Kunttu, Kaja Tampere in Maria Beatriz Torres. 2020. "Bullying in University between Peers and by Personnel: Cultural Variation in Prevalence, Forms, and Gender Differences in Four Countries." Social Psychology of Education 23 (1): 143-69. 
Rey, Rosario Del, Lambros Lazuras, José A. Casas, Vassilis Barkoukis, Rosario Ortega-Ruiz in Haralambos Tsorbatzoudis. 2016. "Does Empathy Predict (Cyber) Bullying Perpetration, and How Do Age, Gender and Nationality Affect This Relationship?" Learning and Individual Differences 45: 275-81.

Salmivalli, Christina. 2010. "Aggression and Violent Behavior Bullying and the Peer Group : A Review.” Aggression and Violent Behavior 15 (2): 112-20.

Salmivalli, Christina, in Kätlin Peets. 2009. "Handbook of Peer Interactions, Relationships, and Groups." V Handbook of Peer Interactions, Relationships, and Groups.

Slonje, Robert in Peter K. Smith. 2008. "Cyberbullying: Another Main Type of Bullying?: Personality and Social Sciences.” Scandinavian Journal of Psychology 49 (2): 147-54.

Stadler, Christina, Julia Feifel, Sonja Rohrmann, Robert Vermeiren in Fritz Poustka. 2010. "Peer-Victimization and Mental Health Problems in Adolescents: Are Parental and School Support Protective?" Child Psychiatry and Human Development 41 (4): 371-86.

Twemlow, Stuart W. in Frank C. Sacco. „Bullying is everywhere: Ten universal truths about bullying as a social process in schools \& communities.“ Psychoanalytic Inquiry 33.2 (2013): 73-89.

Wang, Jing, Ronald J. Iannotti in Tonja R. Nansel. 2009. "School Bullying Among Adolescents in the United States: Physical, Verbal, Relational, and Cyber." Journal of Adolescent Health 45 (4): 368-75.

Zych, Izabela, Maria M. Ttofi in David P. Farrington. 2019. "Empathy and Callous-Unemotional Traits in Different Bullying Roles: A Systematic Review and Meta-Analysis." Trauma, Violence, and Abuse 20 (1): 3-21. 